ISSN 1112-9867

http://www.jfas.info

\title{
SEQUENCE CRYSTALLIZATION DURING ISOTHERM EVAPORATION OF SOUTHERN ALGERIA CHOTT BAGHDAD NATURAL BRINE
}

\author{
M. Zatout ${ }^{1, *}$, M. Hacini ${ }^{1}$, A. H. Hamzaoui ${ }^{2}$, A. M' nif ${ }^{2}$ \\ ${ }^{1}$ Laboratoire de Géologie du Sahara, Université Kasdi Merbah Ouargla, BP 511. 30000 \\ Ouargla, Algérie \\ ${ }^{2}$ Laboratoire de Valorisation des Matériaux Utiles, Centre National de Recherche en Sciences \\ des Matériaux, Technopole Borj Cedria, B.P. 73, 8027 Soliman, Tunisie
}

Received: 06 Febraury 2017 / Accepted: 22 April 2017 / Published online: 01 May 2017

\begin{abstract}
Southern Algerian's natural brine sampled from chott Baghdad may be a source of mineral salts with a high economic value. These salts are recoverable by simple solar evaporation. Indeed, during isothermal solar evaporation, it is possible to recover mineral salts and to determine the precipitation sequences of different salts as a function of the chemical composition and the density of the brine. In this study, the variation of ionic composition of concentrated brine during isothermal evaporation was measured; then the experimental pathway of the point representing its composition on the oceanic fivefold diagram $\mathrm{Na}^{+}, \mathrm{K}^{+}$, $\mathrm{Mg}^{2+}, \mathrm{Cl}^{-}, \mathrm{SO}_{4}{ }^{2-} / / \mathrm{H}_{2} \mathrm{O}$ was plotted. In order to follow the precipitation sequences of mineral salts, during solar evaporation at $35^{\circ} \mathrm{C}, \mathrm{X}$-Ray diffraction was performed on the precipitated and removed salts from the brine during evaporation.
\end{abstract}

Keywords: seawater quinary diagram, Jänecke projection, isothermal evaporation, mineral salts, chott Baghdad brine.

Author Correspondence, e-mail: zatoutm@gmail.com

http://dx.doi.org/10.4314/jfas.v9i2.22 


\section{INTRODUCTION}

The Sebkhats of south Algeria contain a high volume of natural brine, which represents enormous resources for extraction of dissolved salts [1]. Sodium chloride has already recovered from Melghir and Merouane chotts. Potassium and magnesium salts may be recovered. Indeed, during isothermal solar evaporation it is possible to recover mineral salts and to determine the precipitation sequences of the different salts as a function of the composition and the density of the brine. These observations lead us to examine the case of chott Baghdad natural brine. With regard of this aim, the variations of the ionic compositions of chott Baghdad brine during isothermal evaporation at $35^{\circ} \mathrm{C}$ will be studied. XRD was performed to determine the precipitated salts during evaporation. The precipitation sequences of mineral salts, during isothermal evaporation at $35^{\circ} \mathrm{C}$, are established and the experimental pathway of this brine during its evolution was plotted on the oceanic fivefold seawater diagram $\left(\mathrm{Na}^{+}, \mathrm{K}^{+}, \mathrm{Mg}^{2+}, \mathrm{Cl}^{-}, \mathrm{SO}_{4}{ }^{2-} / / \mathrm{H}_{2} \mathrm{O}\right)$.

\section{MATERIALS AND METHODS}

\subsection{Experimental}

The ionic composition of the chott Baghdad natural brine studied is given in Table 1.

Table 1. Ionic composition of the chott Baghdad brine (g. $\left.1^{-1}\right)$

\begin{tabular}{lllllll}
\hline Density & $\mathbf{N a}^{+}$ & $\mathbf{M g}^{2+}$ & $\mathbf{K}^{+}$ & $\mathbf{C a}^{2+}$ & $\mathbf{C l}^{-}$ & $\mathbf{S O}_{4}{ }^{2-}$ \\
\hline 1,223 & 89,00 & 8,14 & 9,60 & 0,40 & 155,43 & 15,00 \\
\hline
\end{tabular}

Four liters of the above brine were evaporated in a glass vessel and placed in a thermostatic bath, which was maintained at $35^{\circ} \mathrm{C}$. The crystallized salts were separated by filtration, as well as they were formed. Then the solid and the liquid phases were characterized (solutions were designated $\mathrm{Si}, \mathrm{i}=1$ à 6 and solids were designated Salt-i). X Rays powder diffraction was used to characterize the solid phase, and chemical analysis and density measures were used to characterize the liquid.

The experimental pathway representing the evolution of the evaporated brine's composition was then plotted on the Jänecke projection at $35^{\circ} \mathrm{C}$ of the quinary diagram $\mathrm{Na}^{+}, \mathrm{K}^{+}, \mathrm{Mg}^{2+}, \mathrm{CI}^{-}$, $\mathrm{SO}_{4}{ }^{2-} / / \mathrm{H}_{2} \mathrm{O}$. 


\subsection{Location of the chott Baghdad brine on the quinary diagram}

The Jänecke coordinates of the point representing the chott Baghdad natural brine on the oceanic quinary diagram $\mathrm{Na}^{+}, \mathrm{K}^{+}, \mathrm{Mg}^{2+}, \mathrm{Cl}^{-}, \mathrm{SO}_{4}{ }^{2-} / / \mathrm{H}_{2} \mathrm{O}$ [2] were calculated using the following equations:

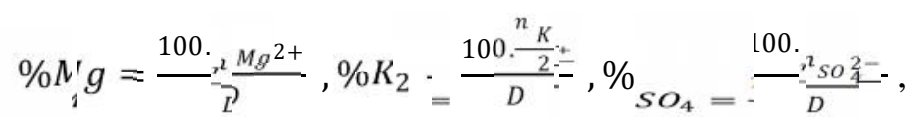

$$
\begin{aligned}
& \text { with, } D=n_{M_{l}^{2+}}+\frac{n_{K^{+}}}{2}+n_{S O_{4}^{2-}} \text { and } n_{\mathrm{i}} \text { the mole number of the } \mathrm{i} \text { entity }
\end{aligned}
$$

Using the above mentioned results in Table 1 and these equations, the Jänecke coordinates are as follows:

$$
\begin{gathered}
\% \mathrm{Mg}=29,13 \\
\% \mathrm{~K}_{2}=17,18 \\
\% \mathrm{SO}_{4}=53,69
\end{gathered}
$$

Fig.1. indicates the location of the chott Baghdad natural brine on the oceanic quinary diagram $\mathrm{Na}^{+}, \mathrm{K}^{+}, \mathrm{Mg}^{2+}, \mathrm{CI}^{-}, \mathrm{SO}_{4}{ }^{2-} / / \mathrm{H}_{2} \mathrm{O}$. The chott Baghdad natural brine is located in the Glaserite crystallization field. This position helps us to predict its theoretical pathway.

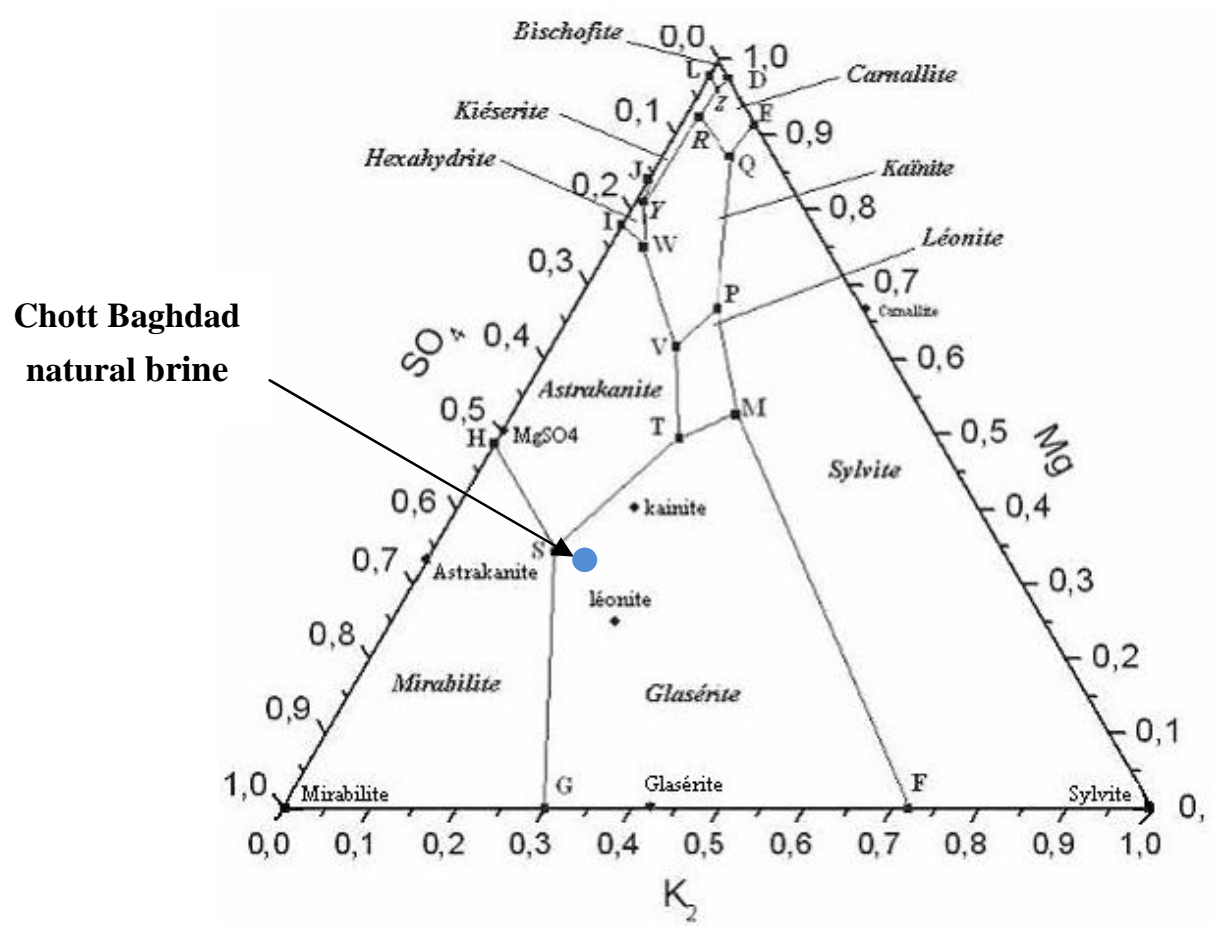

Fig.1. Location of the representative point of the studied brine on the oceanic quinary diagram $\mathrm{Na}^{+}, \mathrm{K}^{+}, \mathrm{Mg}^{2+}, \mathrm{CI}^{-}, \mathrm{SO}_{4}{ }^{2-} / / \mathrm{H}_{2} \mathrm{O}$ at $35^{\circ} \mathrm{C}$. 


\subsection{Theoretical pathway}

According to the composition and the geometrical position of the chott Baghdad natural brine's, its theoretical pathway is represented on the oceanic fivefold diagram $\mathrm{Na}^{+}, \mathrm{K}^{+}, \mathrm{Mg}^{2+}$, $\mathrm{CI}^{-}, \mathrm{SO}_{4}{ }^{2-} / / \mathrm{H}_{2} \mathrm{O}$ at $35^{\circ} \mathrm{C}$, given in Fig.2. Our prediction is based on Gibbs law: $\mathrm{v}=\mathrm{c}-\Phi$

- $\quad \mathrm{v}:$ system variance

- $\Phi$ : phase number

- $\quad \mathrm{c}:$ independents constituants number

In the case of oceanic quinary system, all the solutions are permanently saturated with $\mathrm{NaCl}$. So, when a representative point is situated on a given plan (crystallization field), that means $\mathrm{v}=2=5-\Phi$; thus, $\Phi=3$, Two salts and one solution. Consequently, the evaporation of chott Baghdad natural brine will give the following theoretical sequences:

Table 2. Predicted salts sequences

\begin{tabular}{|c|c|c|}
\hline $\begin{array}{l}\text { Sequence } \\
\text { number }\end{array}$ & Pathway & Crystallized salts \\
\hline 1 & $\alpha \alpha^{\prime}(\mathrm{v}=3)$ & Halite $(\mathrm{NaCl})$ \\
\hline 2 & $\alpha^{\prime} \beta(v=2)$ & Halite + Glasérite $\left(\mathrm{Na}_{2} \mathrm{SO}_{4} \cdot 3 \mathrm{~K}_{2} \mathrm{SO}_{4}\right)$ \\
\hline 3 & $\beta \mathrm{T}$ & $\mathrm{NaCl}+$ Glaserite + Astrakanite $\left(\left(\mathrm{Na}_{2} \mathrm{SO}_{4} \cdot \mathrm{MgSO}_{4} \cdot 4 \mathrm{H}_{2} \mathrm{O}\right)\right.$ \\
\hline 4 & Point $\mathrm{T}$ & $\begin{array}{l}\text { Decomposition of Glaserite and apparition of Leonite }\left(\mathrm{K}_{2} \mathrm{SO}_{4} \text {. }\right. \\
\left.\mathrm{MgSO}_{4} \cdot 4 \mathrm{H}_{2} \mathrm{O}\right)\end{array}$ \\
\hline 5 & $\mathrm{TV}$ & Halite + Astrakanite + Leonite. \\
\hline 6 & V Point & $\begin{array}{l}\text { Dissolution of Leonite and apparition of Kaïte }\left(\mathrm{KCl} \mathrm{MgSO}_{4} \text {. }\right. \\
\left.3 \mathrm{H}_{2} \mathrm{O}\right)\end{array}$ \\
\hline 7 & VW & Halite + Astrakanite + Kaïte \\
\hline 8 & & $\begin{array}{l}\text { This pathway continued till } Z \text { point if the amount of water is } \\
\text { enough }\end{array}$ \\
\hline
\end{tabular}




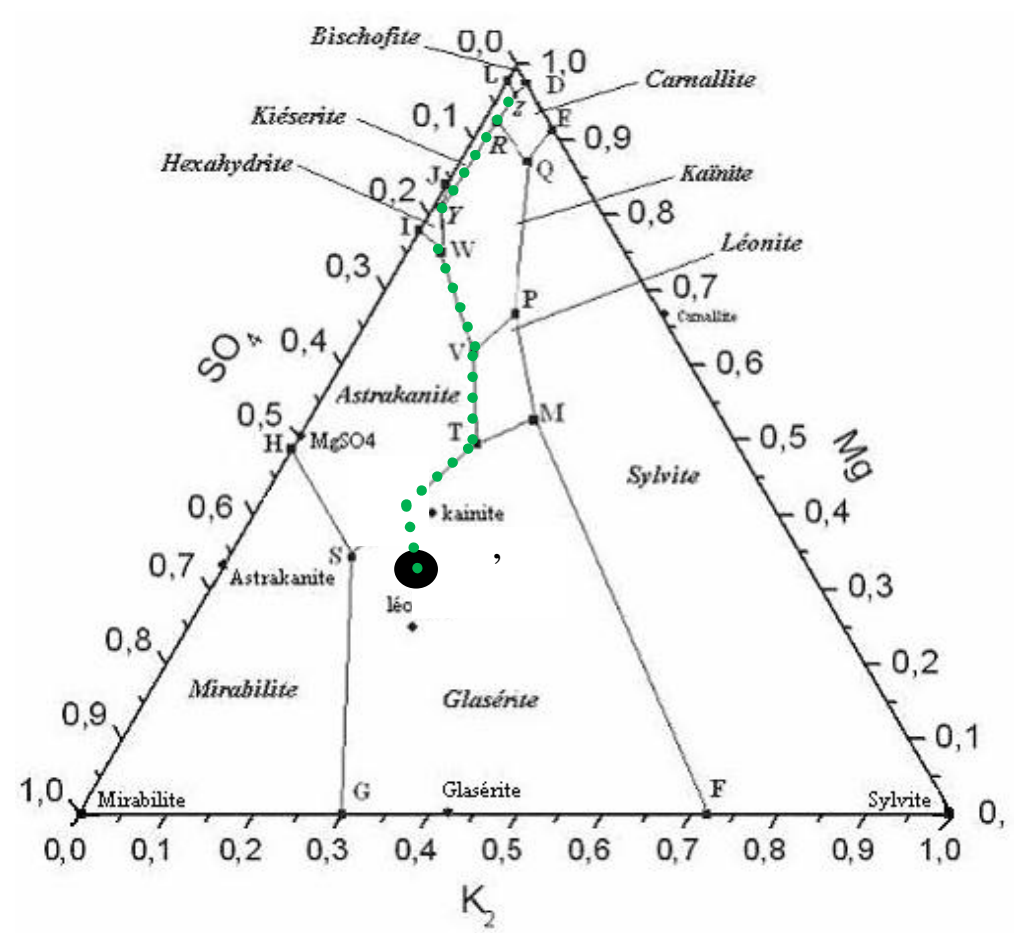

Fig.2. Theoretical pathway of the studied brine on the oceanic quinary diagram

$$
\mathrm{Na}^{+}, \mathrm{K}^{+}, \mathrm{Mg}^{2+}, \mathrm{CI}^{-}, \mathrm{SO}_{4}{ }^{2-} / / \mathrm{H}_{2} \mathrm{O} \text { at } 35^{\circ} \mathrm{C} \text {. }
$$

At $\mathrm{Z}$ point (true invariant point), the solution does not move and will carry on the evaporation till drying. Fig. 2 represents the above pathway followed by the brine on the quinary diagram. It is important to mention that this theoretical crystallization sequence is not almost respected due to metastable phenomena and supersaturated solutions $[3,4,5]$.

\section{RESULTS AND DISCUSSION}

\subsection{Results}

The ionic composition and densities of the brine during the evaporation process are presented on Table 3. The ionic composition of the precipitated salts is given on Table 4 .

As made for natural brine coordinates calculations ( $\$ 2.2$ ), we have determined those of the different solutions in evolution.

The obtained points were projected in Fig.3. This corresponds to the evaporation pathway followed by the brine.

X-Ray diffraction of recovered mineral salts during evaporation is presented by Fig.4. to Fig.7. 
Table 3. Ionic compositions $\left(\mathrm{g} . \mathrm{l}^{-1}\right)$ of the studied brine at $35^{\circ} \mathrm{C}$

\begin{tabular}{llllllll}
\hline Solution & Density & $\mathbf{C a}^{2+}$ & $\mathbf{M g}^{2+}$ & $\mathbf{N a}^{+}$ & $\mathbf{K}^{+}$ & $\mathbf{C l}^{-}$ & $\mathbf{S O}_{4}{ }^{2-}$ \\
\hline NS & 1,223 & 0,40 & 8,14 & 89,00 & 9,60 & 155,43 & 15,00 \\
S1 & 1,235 & 0,12 & 14,45 & 72,00 & 13,60 & 152,70 & 23,00 \\
S2 & 1,254 & 0,00 & 21,68 & 58,00 & 18,07 & 150,00 & 31,82 \\
S3 & 1,275 & 0,00 & 28,00 & 52,00 & 23,43 & 147,13 & 37,93 \\
S4 & 1,289 & 0,00 & 37,98 & 34,00 & 33,79 & 145,78 & 47,27 \\
S5 & 1,293 & 0,00 & 42,90 & 20,00 & 36,34 & 159,45 & 39,45 \\
S6 & 1,305 & 0,00 & 45,00 & 18,00 & 33,45 & 165,89 & 33,67 \\
\hline
\end{tabular}

Table 4. Ionic composition (\%) of the solid phase salts recovered during isothermal evaporation at $35^{\circ} \mathrm{C}$.

\begin{tabular}{llllllll}
\hline Salt & Density & $\mathbf{C a}^{2+}$ & $\mathbf{M g}^{2+}$ & $\mathbf{N a}^{+}$ & $\mathbf{K}^{+}$ & $\mathbf{C l}^{-}$ & $\mathbf{S O}_{4}{ }^{2-}$ \\
\hline Salt-1 & 1,235 & 0,42 & 0,15 & 37,56 & 0,10 & 60,76 & 1,41 \\
Salt-2 & 1,254 & 0,08 & 0,19 & 37,23 & 0,22 & 61,18 & 1,17 \\
Salt-3 & 1,275 & 0,00 & 0,12 & 35,25 & 0,24 & 53,58 & 3,99 \\
Salt-4 & 1,289 & 0,00 & 0,14 & 33,00 & 0,93 & 39,70 & 20,30 \\
Salt-5 & 1,293 & 0,00 & 0,60 & 22,86 & 18,10 & 20,77 & 43,57 \\
Salt-6 & 1,305 & 0,00 & 0,78 & 22,86 & 21,27 & 22,92 & 47,71 \\
\hline
\end{tabular}




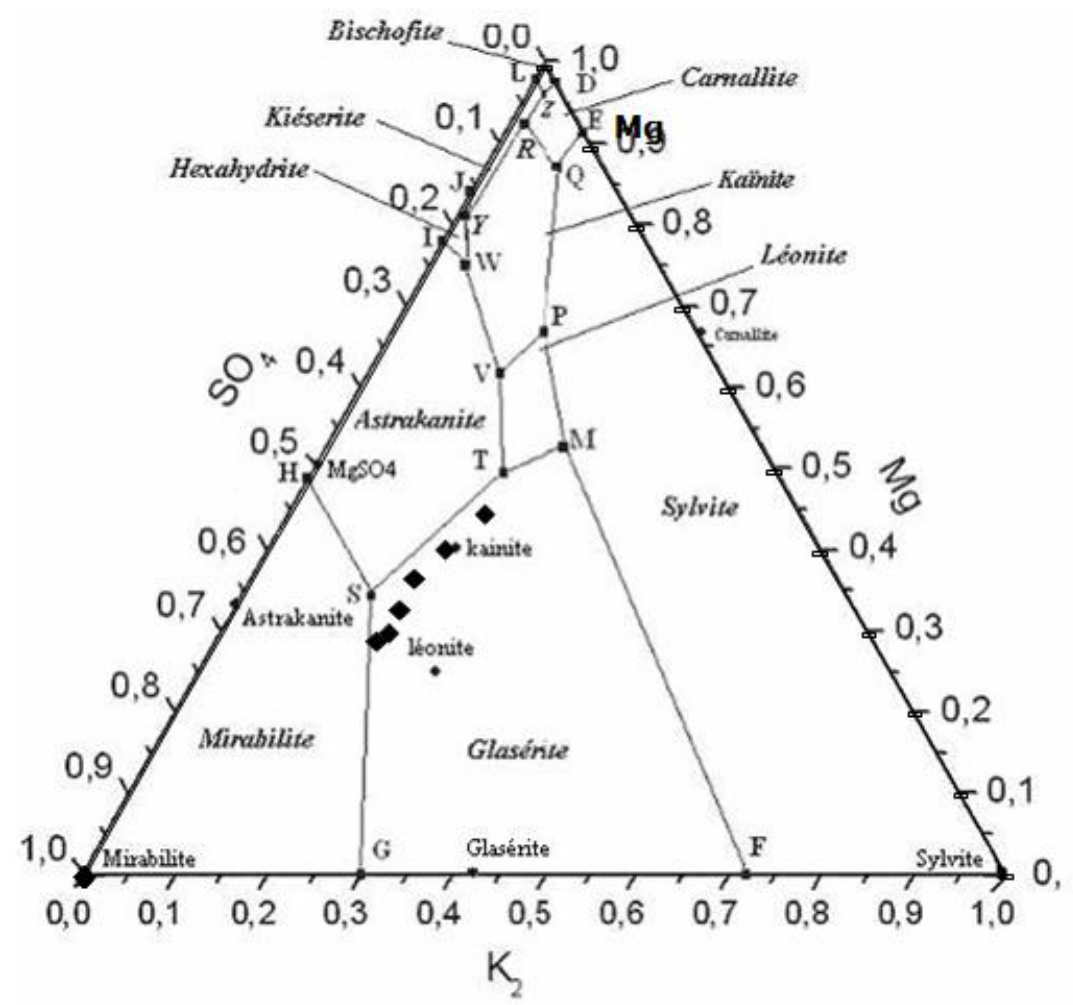

Fig.3. Experimental pathway of chott Baghdad brine on the oceanic quinary diagram $\mathrm{Na}^{+}, \mathrm{K}^{+}$,

$$
\mathrm{Mg}^{2+}, \mathrm{Cl}^{-}, \mathrm{SO}_{4}{ }^{2-} / / \mathrm{H}_{2} \mathrm{O} \text { at } 35^{\circ} \mathrm{C} \text {. }
$$

This pathway is completely different from the theoretical one mentioned in Fig.2.

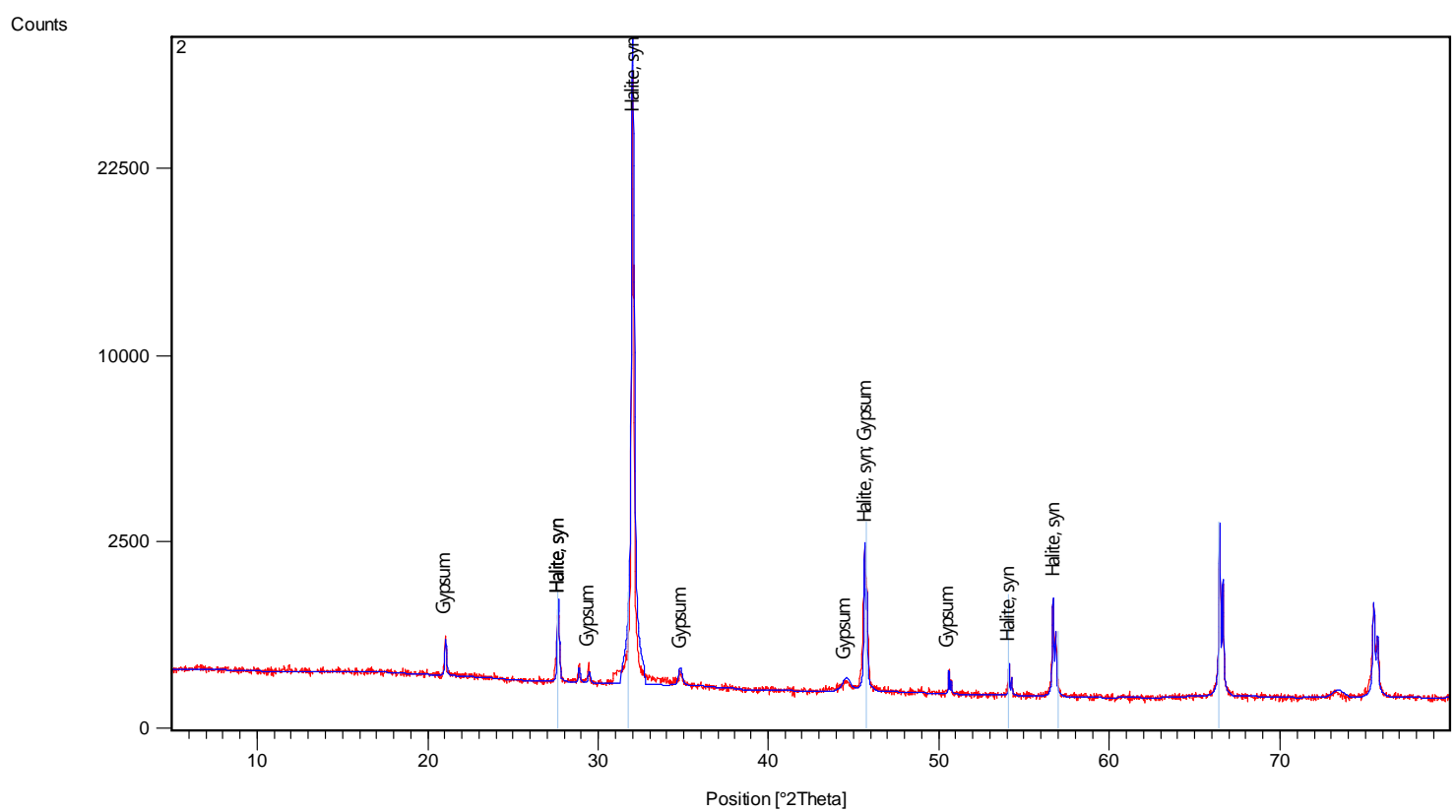

Fig.4. XR Diffraction of Salt-2: Halite $\mathrm{NaCl}$ and Gypsum 


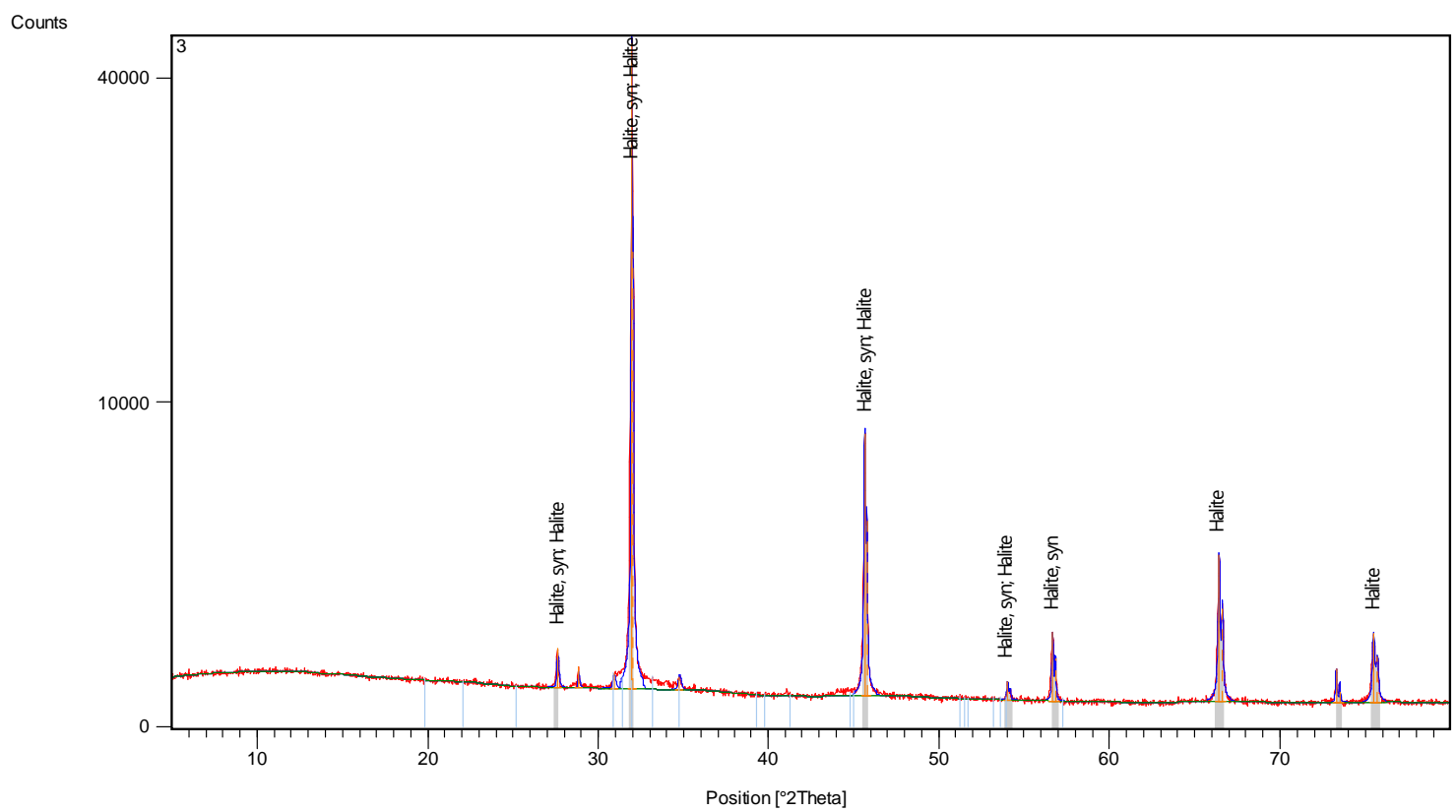

Fig.5. XR Diffraction of Salt-4: Halite.

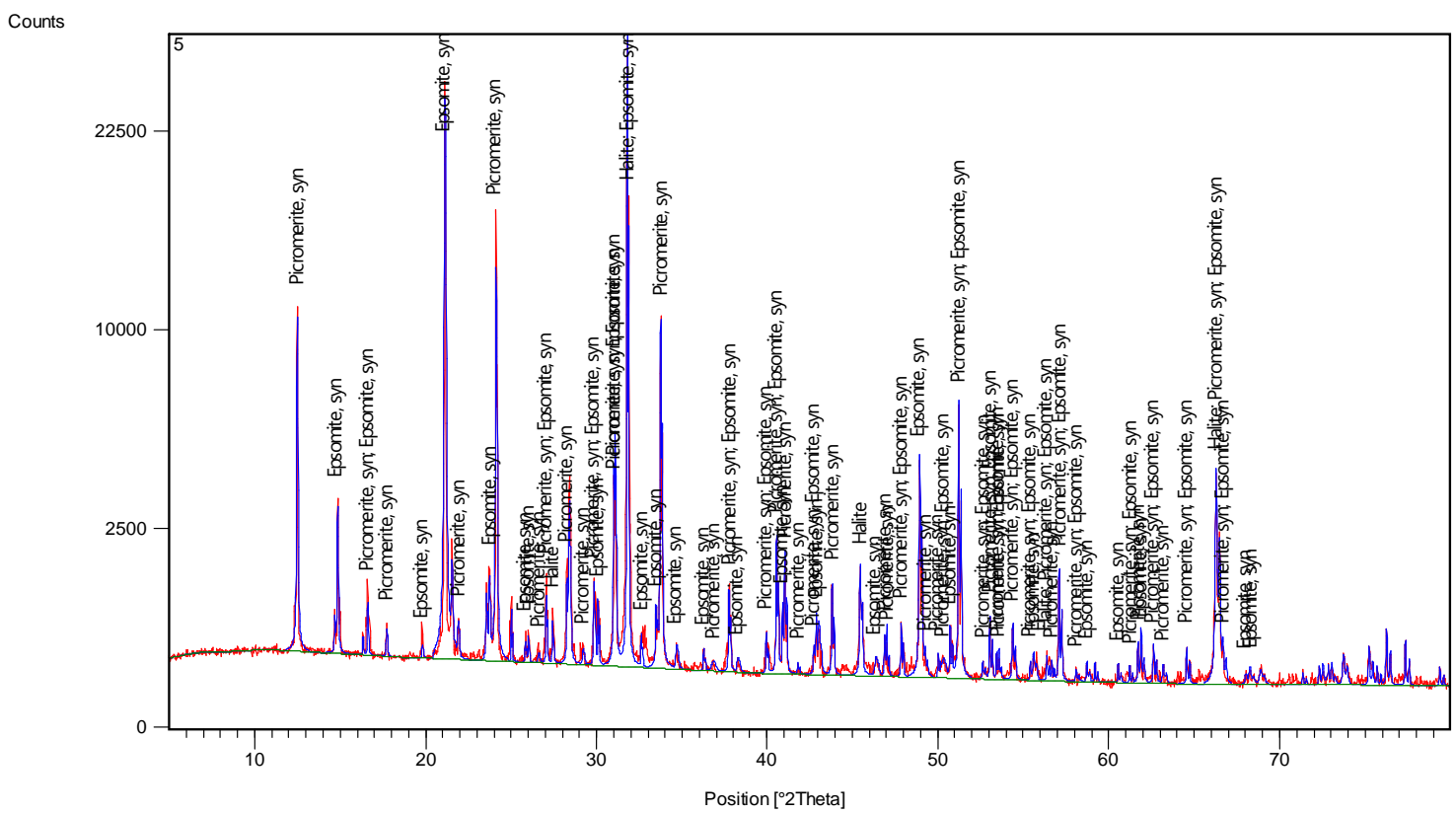

Fig.6. XR Diffraction of Salt-5: Halite, Picromerite and Epsomite. 


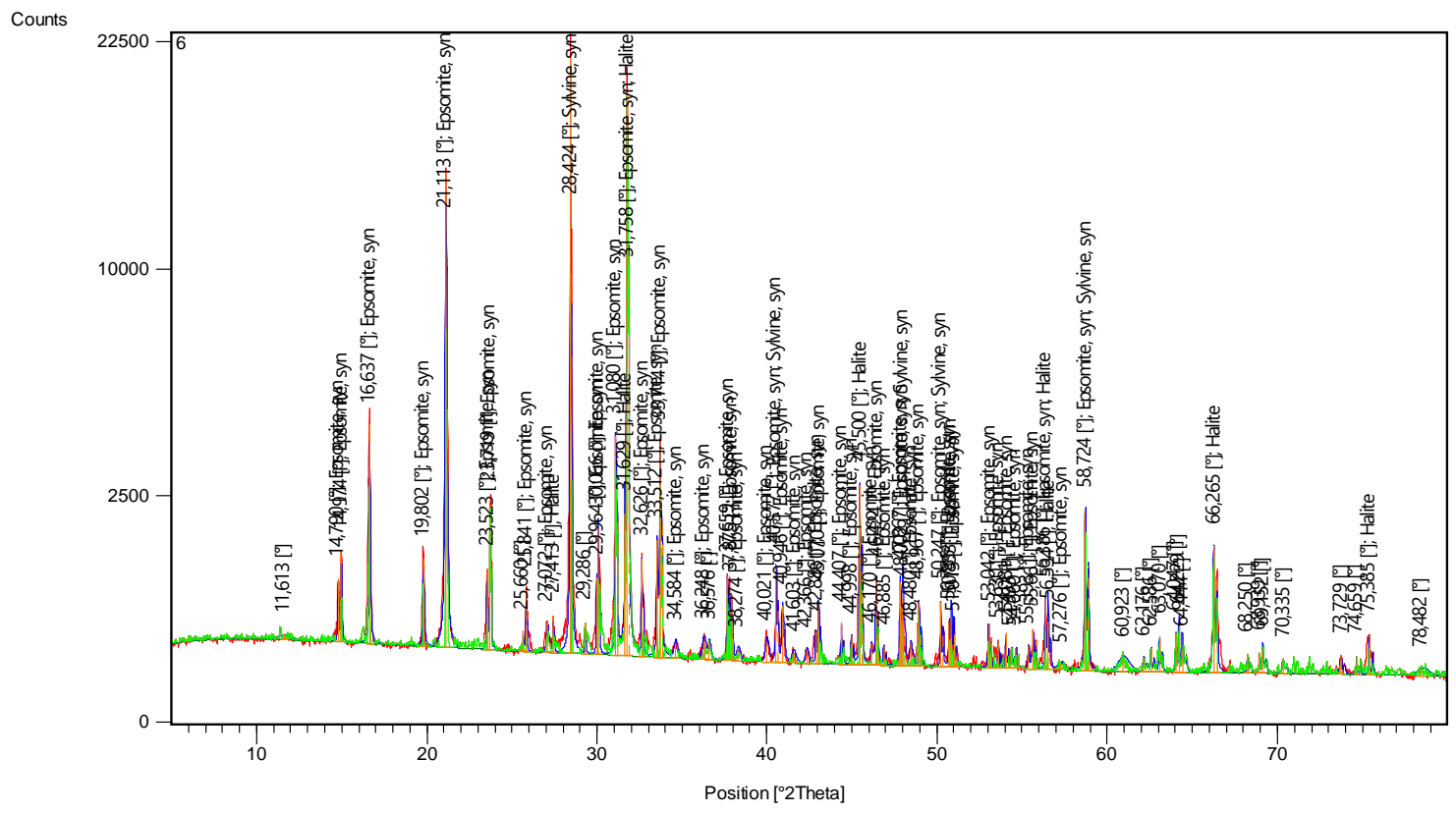

Fig.7. XR Diffraction of Salt-6: Halite, Epsomite and Sylvite.

The above diffractograms allow us to establish the mineralogical composition of the recovered salts. The results are listed on Table 5. The obtained salts sequences are completely different from those predicated on Table 2.

Table 5. Mineralogical identification of recovered salts

\begin{tabular}{lll}
\hline Salt & Density & Solid phase salts (identified by XRD) \\
\hline Salt-1 & 1,235 & Gypsum + Halite \\
Salt-2 & 1,254 & Gypsum + Halite \\
Salt-3 & 1,275 & Halite \\
Salt-4 & 1,289 & Halite \\
Salt-5 & 1,293 & Halite + Picromerite $\left(\mathrm{MgSO}_{4} \mathrm{~K}_{2} \mathrm{SO}_{4} \cdot 6 \mathrm{H}_{2} \mathrm{O}\right)+$ Epsomite $\left(\mathrm{MgSO}_{4} \cdot 7 \mathrm{H}_{2} \mathrm{O}\right)$ \\
Salt-6 & 1,305 & Halite + Sylvite $(\mathrm{KCl})+$ Epsomite \\
\hline
\end{tabular}

\section{DISCUSSION}

Table 5. shows the apparition of Sodium Chloride between densities from 1,235 to 1,289. In 
the first stage, Halite was accompanied with Gypsum $(\mathrm{d}=1,235 \div 1,254)$ and then became alone $(\mathrm{d}=1,254 \div 1,289)$, the gypsum apparition is explained by the presence of minor amounts of Calcium in the initial solution as mentioned in Table 1. This solution is concentrated in Sulfate ion. Consequently and with regard to its very low solubility, Gypsum will precipitate. These Two sequences represent only one which agrees with the predicted one (Table 2. sequence number 1).

Salt-5, precipitated between $\mathrm{d}=1,289$ and $\mathrm{d}=1,293$ is a mixture of Sodium Chloride, Picromerite $\left(\mathrm{MgSO}_{4} \mathrm{~K}_{2} \mathrm{SO}_{4} .6 \mathrm{H}_{2} \mathrm{O}\right)$ and Epsomite $\left(\mathrm{MgSO}_{4} \cdot 7 \mathrm{H}_{2} \mathrm{O}\right)$. This sequence is different from the predicted one. Also salt- 6 which crystallized between $d=1,293$ and $d=1,305$ consists of Halite, Sylvite $(\mathrm{KCl})$ and Epsomite, is different from the foreseeable last sequences as indicated in Table 2.

So, the plotted experimental crystallization pathway didn't confirm the predicted one. Effectively, the different points of chott Baghdad natural brine evaporated were inside the Glaserite $\left(\mathrm{Na}_{2} \mathrm{SO}_{4} \cdot 3 \mathrm{~K}_{2} \mathrm{SO}_{4}\right)$ crystallization field (Fig.3.), but experimentally this salt (Glaserite) was missed and replaced by Picromerite and Epsomite. Moreover, the last point, which represents the last solution S6, still in the Glaserite field and the final salt is formed by Halite, Sylvite and Epsomite, instead of Halite, Astrakanite $\left(\mathrm{Na}_{2} \mathrm{SO}_{4} \cdot \mathrm{MgSO}_{4} \cdot 4 \mathrm{H}_{2} \mathrm{O}\right)$ and Glaserite $\left(\mathrm{Na}_{2} \mathrm{SO}_{4} \cdot 3 \mathrm{~K}_{2} \mathrm{SO}_{4}\right)$.

The exam of recovered salts shows that only the first sequence agrees with the predicted one. Glaserite and Astrakanite are missed. Similar observations were made by F. Khalissa and all [3] according to their work on the Zarzis Sabkhat El Mellah south Tunisia brine, where Epsomite takes place of Astrakanite and Glaserite. Moreover, the same phenomenon was observed by A. M'nif and R. Rokbani [4] when they have studied the Sabkhat El Adhibate and Sabkhat El Mellah natural brines, where Epsomite takes place of Astrakanite.

The above established differences between foreseeable and experimental crystallization sequences corroborate perfectly with the result reached by Kurnakow and Nikolaew when they have studied the solar diagram as it is reported by Balarew [5]. Indeed, on the solar diagram, the solubility fields of astrakanite, kainite and kieserite are missed, that's what makes the Epsomite replace Astrakanite. The same observation was made by Neitzel as it is 
reported by A. M'nif [4]. Indeed, according to his work on the Great Salt Lake brine, he mentioned that Astrakanite and some others double salts do crystallize only when respective nuclei are present in the system. Furthermore, M'nif and Rokbani [4] observe that the recovered mixture of halite and Epsomite convert completely into Astrakanite after a long period. Thus, astrakanite is a secondary mineral.

Glaserite didn't crystallize because of its slower kinetic comparing with Epsomite or Sylivite [4]. It is established that when seconds are needed for $\mathrm{KCl}$ and $\mathrm{NaCl}$ crystallization, minutes are needed for Picromerite $\left(\mathrm{MgSO}_{4} \mathrm{~K}_{2} \mathrm{SO}_{4} .6 \mathrm{H}_{2} \mathrm{O}\right)$, and hours are needed for Leonite $\left(\mathrm{MgSO}_{4}\right.$ $\left.\mathrm{K}_{2} \mathrm{SO}_{4} .4 \mathrm{H}_{2} \mathrm{O}\right)$ and Glaserite $\left(\mathrm{Na}_{2} \mathrm{SO}_{4} .3 \mathrm{~K}_{2} \mathrm{SO}_{4}\right)$ crystallization [6].

\section{CONCLUSION}

The obtained results confirm that Jänecke projection is indicated to study the high concentrated brine because of its pertinence and simplicity. The crystallization sequences determined to chott Baghdad natural brine are: Gypsum, Halite, Picromerite, Epsomite and Sylvite. Only for the first sequence, a good correlation is observed between predictable evolution and experimental one. After that, a clear deviation is reported. It is mainly caused by kinetic considerations as explained before. It is well known that high concentrated Magnesium solutions form a $\left[\mathrm{Mg}\left(\mathrm{H}_{2} \mathrm{O}\right)_{6}\right]^{2+}$ complex [7] which steers the future pathway salts crystallization. In this case, some crystallization surfaces, which didn't have the octahedral crystalline form like the complex already mentioned become so flexible and penetrate the juxtaposed salt field's to precipitate it, before crystallizing its own salt. This is the case of Glaserite. Astrakanite and other double salts do crystallize only when respective nuclei are present in the system, they are secondary minerals [4].

\section{REFERENCES}

[1] : Hacini M, Oelkers E.H, and Kherici N. Mineral precipitation spleens during the supplements evaporation of the Merouane Chott ephemeral lake. Geochim. Cosmochim. Acta, 72 (2008) 1583-1597.

[2] : Fezei R, Hammi H and M'nif A. Selective recovery of Bischofite from Sebkha El Melah 
natural brine, L atin American Applied Research, 39 (2009) 375-380.

[3] : Khalissa F, M'nif A, and Rokbani R. Application du modèle de Pitzer à l'étude de l'évaporation solaire isotherme des saumures naturelles, J. Phys. IV France. 122(2004) 253-256.

[4] : M'nif A, and Rokbani R. Minerals successions crystallisation related to Tunisian natural brines, cryst. Res. Technol. 39 (2004) 40-49.

[5]: Balarew C. Solubilities in seawater-type systems: some technical and environmental friendly applications, Pure Appl. Chem. 65 (1993) 213-218.

[6] : Autenrieth H. Kali und Steinsalz 11, 317(1953).

[7] : Prigogine I, and Defay R. Thermodynamique chimique (DESOER, 1950), p.474.

\section{How to cite this article:}

Zatout M, Hacini M, Hamzaoui A.H, and M'nif A. sequence crystallization during isotherm evaporation of southern algeria chott baghdad natural brine J. Fundam. Appl. Sci., 2017, 9(2), 959-970. 